\title{
Experimental Study on Method of Measuring Cytochrome P450 in Fish Liver subcellular fractions
}

\author{
Shen Mengnan ${ }^{1 *}$, Li Na ${ }^{2}$, Wu Ruohan ${ }^{3}$ \\ 1. Key Laboratory of Songliao Aquatic Environment, Ministry of Education, Jilin Jianzhu University, \\ Changchun 130118, P.R. China \\ 2. Key Laboratory of Songliao Aquatic Environment, Ministry of Education, Jilin Jianzhu University, \\ Changchun 130118, P.R. China \\ 3. State Key Laboratory of Pollution Control and Resource Reuse; School of the Environment, \\ Nanjing University, Nanjing 210023, P.R. China \\ 1.email: smn930@aliyun.com
}

Keywords: CYP450, fish, enzyme active

\begin{abstract}
To study the method of measuring cytochrome P450 (CYP450) in fish liver subcelluar fractions ( S9 and microsomes). Fish liver microsome was obtained by differential velocity centrifugation, the concentration of protein of liver microsome was measured by Bradford, and the activity of mice CYP450 was detected by spectrophotometer. The result showed that this method is easy and reliable, and has good reproducibility.
\end{abstract}

\section{Introduction}

Study in vitro can effectively reduce the dosage of the living creature, well expel the interference of complex factors in vivo. The metabolism selectivity of enzyme to substrate could be direct observed. Thus, the study method in vitro has been widely used in a variety of study on drugs and pollutants metabolism. At present, two kinds of liver subcellular fractions: one is after the removal of mitochondrial homogenate supernatant(S9), another is the liver microsome were used at most in vitro study. Cytochrome P450 (CYP 450) isozymes were the major phase I catalyze isozymes in liver. Ethoxycoumarin O-deethylase (ECOD), Ethoxyresorufin O-deethylase (EROD), pentoxyresorufin O-deethylase (PROD) and aniline hydroxylase (AH) were several common used to characterize of CYP450 enzyme activity. Glutathione S-transferase (GST) is one of important phase II metabolic enzymes. The freshwater fish crucian carp (Carassius auratus) was chosen as the test animal, and the effect on several major metabolic enzyme activities, including extracting methods of liver microsome, incubation temperature and enzyme inducers was investigated.

\section{Materials and methods}

Fish were dosed via intraperitoneal (i.p.) injection of normal saline, phenobarbital(PB) (80 $\mathrm{mg} / \mathrm{kg} \mathrm{b.w.} \mathrm{/day)} \mathrm{and} \mathrm{hexadecadrol} \mathrm{(DEX)(100} \mathrm{mg/kg} \mathrm{b.w.} \mathrm{/day),} \mathrm{separately.} \mathrm{All} \mathrm{injections} \mathrm{were}$ standardized to ensure a final injection volume of $0.1 \mathrm{~mL}$ and fish were injected daily for 3 consecutive days. After the 3-day exposure, the fish were killed by a sharp blow to the head. Livers were quickly removed, rinsed in ice-cold $0.9 \% \mathrm{NaCl}$ solution, and weighed. The liver tissues were homogenized in a $0.1 \mathrm{M}$ Tris-HCl buffer. S9 fractions were obtained by centrifugation of the liver homogenates at $9,000 \mathrm{~g}$ for $20 \mathrm{~min}$ at $4{ }^{\circ} \mathrm{C}$. Microsomal pellets were obtained by centrifugation of S9 fractions at $105,000 \mathrm{~g}$ for $60 \mathrm{~min}$ at $4{ }^{\circ} \mathrm{C}$. The microsomal pellet was resuspended in a $0.1 \mathrm{M}$ Tris- $\mathrm{HCl}$ buffer. The microsomal suspension and S9 were divided into aliquots respectively and stored in liquid nitrogen until utilized for in vitro assays. The protein content analysis of subcellular fractions was based on previously reported methods ${ }^{[1]}$.

Ethoxycoumarin O-deethylase (ECOD) activity was measured using a modified method of Greenlee and Poland ${ }^{[2]}$. The product 7-hydroxycoumarin was determined fluorometrically 
(excitation/emission wavelengths of $370 / 450 \mathrm{~nm}$ ) with an HIACHI F-7000 spectrophotofluorimeter. Ethoxyresorufin O-deethylase (EROD) and pentoxyresorufin O-deethylase (PROD) activities were measured using the modified method of Lubet et al. ${ }^{[3]}$. The aniline hydroxylase (AH) activity of the CYP2E1 enzyme was measured with aniline as the substrate according to the procedure described previously ${ }^{[4]}$. Glutathione S-transferase (GST) activities were determined utilizing the broad GST substrate $\mathrm{CDNB}^{[5]}$.

\section{Results and discussion}

Phase I and II xenobiotic metabolizing enzymes play fundamental roles in metabolism and elimination of enobiotics. CYP450 (Phase I ) and GST(Phase II) are important metabolism enzymes in fish liver microsomes and S9. In fish, CYP1A isozymes have been previously reported to catalyze the metabolism of various xenobiotic compounds (PAH, PCBs, dioxins, etc.) ${ }^{[6]}$, whereas CYP3A and CYP2E subfamily are the isozymes presenting predominantly in fish ${ }^{[7]}$.EROD, PROD and $\mathrm{AH}$ can respectively represent CYP1A, CYP2B and CYP2E activity. Another CYP450 enzyme ethoxycoumarin-O-deethylase (ECOD) has been studied in mammals as a marker of activities for CYP1A1, CYP1A2, CYP2B1, CYP2E1, and CYP2B6 ${ }^{[8]}$.

Table 1 compares five enzyme activities in both the liver S9 fraction and microsomes. The phase I enzyme in hepatic microsomes showed the higher catalytic viability $\left(24 \pm 5 \mathrm{pmol} \mathrm{mg}^{-1} \mathrm{~min}^{-1}\right)$ than that of the S9 $\left(4 \pm 1 \mathrm{pmol} \mathrm{mg}^{-1} \mathrm{~min}^{-1}\right)$, as measured by CYP1A-mediated EROD activity. The same pattern was seen in the ECOD activity. Mean ECOD activity of microsomes was $93 \pm 3 \mathrm{pmol} \mathrm{mg}^{-1}$ $\mathrm{min}^{-1}$, and which of $\mathrm{S} 9$ fractions was $31 \pm 4 \mathrm{pmol} \mathrm{mg}^{-1} \mathrm{~min}^{-1}$. Hodson et al.found that EROD activity in rainbow trout liver S9 was 5.1 pmol min $\mathrm{mg}^{-1}$ which was closed to our results ${ }^{[9]}$. The CYP450 enzyme activity in liver microsomes is generally higher than that in the S9, because some phase II enzyme and coenzyme was removed in the microsomes due to further centrifugal.

It is generally believed that ECOD activity and EROD activity can be used to characterize CYP1A activity, our results showed that ECOD activities in both microsomes and S9 were higher than EROD activities which suggested Ethoxycoumarin was a wider catalysis substrate than ethoxyresorufin for CYP450. Lange et al. determined the activities of ECOD, EROD and PROD in the liver of postspawning dab (Limanda limanda), and a biphasic kinetic of ECOD was found which indicated that in addition to CYP 1A a second isozyme catalyses the O-deethylation of ethoxycoumarin in the liver of $\mathrm{dab}^{[10]}$. Neither microsomes nor S9 showed CYP2B-mediated PROD activities when $1 \mu \mathrm{M}$ substrate concentration was tested for pentyloxyresorufin. Parente et al. also found this phenomenon in tilapias liver micorosmes ${ }^{[11]}$. The PROD activity in rainbow trout liver was only $1.7 \mathrm{pmol} \mathrm{min}^{-1} \mathrm{mg}^{-1[12]}$. Therefore, The CYP2B activity in teleost was generally low. The activity of $\mathrm{AH}$ in microsomes was $20 \pm 5 \mathrm{pmol} \mathrm{mg}^{-1} \mathrm{~min}^{-1}$, whereas in S9 fractions it was not detected. In comparison to the phase I enzyme, phase II enzyme GST activity in S9 fractions $\left(183 \pm 45 \mathrm{nmol} \mathrm{mg}^{-1} \mathrm{~min}^{-1}\right)$ exhibited higher levels than that in microsomes $\left(92 \pm 23 \mathrm{nmol} \mathrm{mg}^{-1} \mathrm{~min}^{-1}\right)$. Our results were consistent with other reports of teleost, which showed that the methods in this experiment is reliable.

Table 1. Phase I cytochrome P450 activities and Phase II GST activity in fish liver microsomes and S9 fraction.

\begin{tabular}{ccc}
\hline Enzyme activity $\left(\mathrm{pmol} \mathrm{mg}^{-1} \mathrm{~min}^{-1}\right)$ & Microsomes & S9 \\
\hline ECOD & $93 \pm 3$ & $31 \pm 4$ \\
EROD & $24 \pm 5$ & $4 \pm 1$ \\
PROD & ND. & ND. \\
AH & $20 \pm 5$ & ND. \\
GST & $(9.2 \pm 2.3) \times 10^{4}$ & $(1.83 \pm 0.45) \times 10^{5}$ \\
\hline
\end{tabular}

ND. : not detected.

We found that effect to EROD and ECOD activities of temperature $\left(25^{\circ} \mathrm{C}\right.$ or $\left.37^{\circ} \mathrm{C}\right)$ was not significant (Table 2). Generally considered $37{ }^{\circ} \mathrm{C}$ as the mammals physiological temperature , 
which is also a best temperature of enzyme activity, therefore in the use of rodents or the human body liver subcellular fractions incubation experiment in vitro was generally choose $37{ }^{\circ} \mathrm{C}$ as the incubation temperature. The fish CYP450 enzyme activity of optimum temperature is relatively low compared with mammals, many fish enzyme activity of optimum temperature is about $25{ }^{\circ} \mathrm{C}$, and even some cold water fish is about $15{ }^{\circ} \mathrm{C}$. Therefore, at the time of experiment using fish to fully consider the influence of temperature on enzyme activity, the early studies of CYP450 fish to use higher incubation temperature and detect active reason ${ }^{[13]}$.

Table 2 The EROD and ECOD activities in fish liver microsomes and S9 in different temperature, $25{ }^{\circ} \mathrm{C}$ and $37^{\circ} \mathrm{C}$

\begin{tabular}{llcl}
\hline & \multicolumn{2}{c}{ ECOD activity $\left(\mathrm{pmol} \mathrm{mg} \mathrm{min}^{-1}\right)$} & EROD activity $\left(\mathrm{pmol} \mathrm{mg} \mathrm{min}^{-1}\right)$ \\
\cline { 2 - 4 } $25 \mathrm{C}^{-1} \mathrm{C}$ & Microsomes & 92.4 & 21.5 \\
& $\mathrm{~S} 9$ & 29.7 & 5.3 \\
$37^{\circ} \mathrm{C}$ & Microsomes & 89.6 & 22.4 \\
& S9 & 28.4 & 3.8 \\
\hline
\end{tabular}

CYP450 was a kind of isozymes which have many different specificity substrate, and plays an important role in the compounds transormation. Each CYP450 isozymes has its own specific catalytic substrates, and susceptible to induction and inhibition of certain compounds, which affect the enzyme activity. Phenobarbital (PB) and dexamethasone (DEX) is a classic mammals CYP450 inducers. In this study, the induction effect to CYP450 of PB and DEX in fish liver was detected (Table 3). The results showed that the activity of EROD and the concentrations of protein was increased slightly, while the ECOD and PROD activity have no significant changes. It was indicated that the effect of inducer to CYP450 activity between fish and mammals was differently.

Table 3 Effect of PB and DEX on the fish liver enzyme activity

\begin{tabular}{cccc}
\hline Enzyme activity $\left(\mathrm{pmol} \mathrm{mg} \mathrm{min}^{-1}\right)$ & PB & Dex & Control \\
\hline ECOD & 88.5 & 85.6 & 90.1 \\
EROD & 25.3 & 22.4 & 20.6 \\
PROD & ND. & ND. & ND. \\
\hline Protein content $\left(\mathrm{mg} \mathrm{mL}^{-1}\right)$ & 3.1 & 4.2 & 3.5 \\
\hline
\end{tabular}

\section{References}

[1] Bradford, M.M., A rapid and sensitive method for the quantification of microgram quantities of protein utilizing the principle of protein-dye binding. Analytical Biochemistry, 1976, 72: 248-254.

[2] Greenlee W.F., Poland A., An improved assay of 7-ethoxycoumarin-O-deethylase activity: induction of hepatic enzyme activity in C57BL/6J and DBA/2J mice by Phenobarbital, 3-methylcholanthrene and 2, 3, 7, 8-tetrachlorodibenzo-p-dioxin. Journal of Pharmacological and Experimental Therapeutics, 1978, 205: 596-605.

[3] Lubet, R.A., Nims, R.W., Mayer, R.T., Cameron, J.W., Schechtman, L.M., Measurement of cytochrome P-450 dependent dealkylation of alkoxyphenoxazones in hepatic S9s and hepatocyte homogenates: effects of dicumarol. Mutation Research, 1985, 142: 127-131.

[4] Schenkman, J.B., Remmer, H., Estabrook, R.W., Spectral studies of drug interaction with hepatic microsomal cytochrome. Molecular Pharmacology, 1967, 3: 113-123.

[5] Habig, W.H., Pabst, M.J., Jakoby, W.B., Glutathione S-transferases the first enzymatic step in mereapturic acid formation. Journal of Biological Chemsitry, 1974, 249: 7130-7139.

[6] Van der Oost, R., Beyer, J., Vermeulen, N.P.E., Fish bioaccumulation and biomarkers in environmental risk assessment: a review. Environmental Toxicological Pharmacology, 2003, 13: 57-149.

[7] Baririan, N., Desager, J.P., Petit, M., Horsmans, Y., CYP3A4 activity in four different animal species liver microsomes using 7-benzyloxyquinoline and HPLC/spectrofluorometric determination. Journal of Pharmaceutical and Biomedical Analysis, 2006, 40: 211-214. 
[8] Yamazaki, H., Inoue, K., Turvy, C.G., Guengerich, F.P., Shimada, T., Effects of freezing, thawing, and storage of human liver samples on the microsomal contents and activities of cytochrome P450 enzymes. Drug Metabolism and Disposition, 1997, 25: 168.

[9] Hodson, P.V., Qureshi, K., Noble, C.A.J., Akhtar, P., Brown, R.S., Inhibition of CYP1A enzymes by $\alpha$-naphthoflavone causes both synergism and antagonism of retene toxicity to rainbow trout (Oncorhynchus mykiss). Aquatic Toxicology, 2007, 81: 275-285.

[10] Lange, U., Goksøyr, A., Siebers, D. Karbe, L., Cytochrome P450 1A-dependent enzyme activities in the liver of dab (Limanda limanda): kinetics, seasonal changes and detection limits. Comparative Biochemistry and Physiology Part B, 1999, 123: 361-371.

[11] Parente, TE, De-Oliveira, AC, Silva, IB, Araujo, FG, Paumgartten, FJ, Induced alkoxyresorufin-O-dealkylases in tilapias (Oreochromis niloticus) from Guandu river, Rio de Janeiro, Brazil. Chemosphere, 2004, 54: 1613-1618.

[12] Smith, E.M., Wilson, J.Y., Assessment of cytochrome P450 fluorometric substrates with rainbow trout and killifish exposed to dexamethasone, pregnenolone-16 $\alpha$-carbonitrile, rifampicin, and $\beta$-naphthoflavone. Aquatic Toxicology, 2010, 97: 324-333.

[13] Chambers, J.E., Yarbrough, J.D., Xenobiotic transformation systems in fishes. Comparative Biochemistry and Physiology Part C, 1976, 55(2):77-84. 